\title{
Delta-Like Protein 3
}

National Cancer Institute

\section{Source}

National Cancer Institute. Delta-Like Protein 3. NCI Thesaurus. Code C104256.

Delta-like protein $3(618 \mathrm{aa}, \sim 65 \mathrm{kDa})$ is encoded by the human DLL3 gene. This protein is involved in binding to notch proteins, mesoderm development and neurogenesis. 